\title{
Cloning, Expression, and Regulation of a Glucocorticoid-Induced Receptor in Rat Brain: Effect of Repetitive Amphetamine
}

\author{
Danzhao Wang, ${ }^{1}$ James P. Herman, ${ }^{2}$ Laurel M. Pritchard,, ${ }^{2,3}$ Rebecca H. Spitzer, ${ }^{2,3}$ Rebecca L. Ahlbrand, ${ }^{2,3}$ \\ Gerald L. Kramer, ${ }^{4}$ Frederick Petty, ${ }^{4}$ Floyd R. Sallee, ${ }^{1,2}$ and Neil M. Richtand ${ }^{2,3}$ \\ ${ }^{1}$ Pharmacology Research Center, Children's Hospital Medical Center, Cincinnati, Ohio 45229, 2Department of Psychiatry, \\ University of Cincinnati College of Medicine, Cincinnati, Ohio 45267, ${ }^{3}$ Cincinnati Veterans Affairs Medical Center, \\ Psychiatry Service (V116A), Cincinnati, Ohio 45220, and ${ }^{4}$ Veterans Affairs Medical Center and University of Texas \\ Southwestern Medical Center, Dallas, Texas 75216
}

Behavioral sensitization to psychostimulants involves neuroadaptation of stress-responsive systems. We have identified and sequenced a glucocorticoid-induced receptor (GIR) cDNA from rat prefrontal cortex. The full-length GIR cDNA encodes a 422 amino acid protein belonging to G-protein-coupled receptor superfamily. Although the ligand for GIR is still unknown, the dendrogram construction indicates that GIR may belong to peptide receptor subfamily (e.g., substance $P$ receptor), with more distant relationship to subfamilies of glycoprotein hormone receptors (e.g., thyrotropin receptor) and biogenic amine receptors (e.g., dopamine receptor). GIR shares 31-34\% amino acid identity to the tachykinin receptors (substance $P$ receptor, neurokinin A receptor, and neurokinin B receptor). GIR mRNA is expressed preferentially in brain, and its neuronal expression is relegated to limbic brain regions, particularly in forebrain. GIR transcript levels are increased significantly and persistently in prefrontal cortex for $7 \mathrm{~d}$ after discontinuation of chronic amphetamine exposure. The induction of GIR expression by amphetamine is associated with augmented behavioral activation. These findings suggest that modulation of GIR expression may be involved in behavioral sensitization, and GIR may play a role at the interface between stress and neuroadaptation to psychostimulants.

Key words: GIR; seven-transmembrane spanning receptor; mRNA; prefrontal cortex; chronic amphetamine administration; behavioral sensitization
Behavioral sensitization is a progressive and enduring enhancement of certain behaviors after repetitive stress or stimulant drug administration. It is a useful, well studied model of behavioral plasticity (Antelman et al., 1980; Robinson and Becker, 1986; Kalivas and Duffy, 1989). After repeated, intermittent treatment with stress or stimulant drugs, sensitized behaviors may occur more intensely with a shorter latency or at a lower dose than before behavioral sensitization (Antelman et al., 1980; Segal et al., 1980). The ventral tegmental area, prefrontal cortex, and amygdala seem to mediate the initial development of sensitization to neural substrates, whereas the nucleus accumbens and more distal structures may be involved in its expression (Kalivas and Stewart, 1991; Pierce and Kalivas, 1997; Wolf, 1998). Sensitization is a long-lasting behavioral change accompanied by neuroadaptation (White and Kalivas, 1998; Nestler, 2000), a consequence of new protein synthesis depending on sustained alteration of gene expression (Karler et al., 1993; Sorg and Ulibarri, 1995; Nestler, 2000). For example, $\Delta$ FosB accumulates in the nucleus accumbens long after chronic exposure to drugs of abuse including amphetamine, cocaine, and opiates (Hope et al., 1994; Kelz et al., 1999; Kelz and Nestler, 2000), and NAC-1

Received April 4, 2001; revised Aug. 10, 2001; accepted Aug. 31, 2001.

This work was supported by Department of Veterans Affairs VISN 10 Research Initiative Program Grant, a National Alliance for Research on Schizophrenia and Depression Young Investigator Award, and National Institute of Mental Health Grant 49698. We thank Dr. Lei Yu for critical reading of this manuscript, Dr. John $\mathrm{W}$. Kasckow for generous gift of immortalized rat amygdalar neuronal cells, and Mr. Chad Price for assistance in the GCG software.

Correspondence should be addressed to Dr. Floyd R. Sallee, Pharmacology Research Center, Children's Hospital Medical Center, 3333 Burnet Avenue, Cincinnati, OH 45229. E-mail: salleefr@email.uc.edu.

Copyright (ㄷ) 2001 Society for Neuroscience $0270-6474 / 01 / 219027-09 \$ 15.00 / 0$
mRNA expression remains elevated in the nucleus accumbens for 3 weeks after acute and repeated cocaine administration (Cha et al., 1997). These examples of neuroadaptation are relevant to the human addictive process, in which learned drug-seeking and other behaviors persist long after bouts of drug use are extinguished (Vanderschuren and Kalivas, 2000).

Mechanisms of cross-sensitization between stress and psychostimulants remain elusive, but the activation of the hypothalamic-pituitary-adrenal axis in response to stress may facilitate the development of sensitization and enhance the vulnerability to drug addiction (Koob, 1999). Substance P appears to be a pivotal neurotransmitter implicated in both stress and drug dependence models (Kramer et al., 1998; Murtra et al., 2000). The glucocorticoid-induced receptor (GIR) was originally identified as a stress-response element from a murine thymoma cDNA library treated with glucocorticoid and forskolin (Harrigan et al., 1991). GIR mRNA was further localized to limbic forebrain regions, dorsal and ventral striatum, and hypothalamic nuclei within the mouse CNS (Pesini et al., 1998). Recently, the gene structure of human GIR was described (De Moerlooze et al., 2000; Parker et al., 2000). Although it is known that GIR expression is restricted to brain and thymus and it can be induced by dexamethasone and forskolin, the ligands of this membrane receptor and its functions remain unknown (Harrigan et al., 1989, 1991; Parker et al., 2000).

Given the importance of stress to models of stimulant sensitization, we evaluated this potential stress-responsive GIR gene in neuroadaptation. To explore the functions of GIR in the experimental animal models, we have cloned rat GIR cDNA, characterized its expression and regional localization in brain, and 
provided the first evidence about its potential role in the longterm maintenance of neuroadaptation at the genetic transcriptional level.

\section{MATERIALS AND METHODS}

Animals. Male adult Sprague Dawley rats (200-250 gm; Harlan Sprague Dawley Laboratories, Indianapolis, IN) were housed for a minimum of 2 weeks in a vivarium before use. Animals were killed by decapitation, and the brains were quickly removed and placed on ice for dissection. Dissection was performed using a coronal rodent brain matrix as described (Segal and Kuczenski, 1974). The most anterior brain region was used for assays of prefrontal cortex after removing the olfactory bulb. After dissection, brain regions were frozen in liquid nitrogen and stored at $-80^{\circ} \mathrm{C}$ before use.

Drugs. D-amphetamine (D-AMPH) (Research Biochemicals, Natick, MA) was dissolved in $0.9 \%$ saline. Drug concentrations were calculated as the free base. All injections were subcutaneous in a final volume of 1 $\mathrm{ml} / \mathrm{kg}$ body weight.

$R N A$ preparation and reverse transcription. Total RNA was isolated from rat prefrontal cortex by single-step guanidine thiocyanate-phenol extraction using the TRI REAGENT (Molecular Research Center, Cincinnati, $\mathrm{OH}$ ) following the manufacturer's instruction. The purified RNA was used for the rat GIR cDNA cloning, amplification of both 5' and $3^{\prime}$ cDNA ends. The concentrations of RNA samples were determined by spectrophotometric measurements at 260 and $280 \mathrm{~nm}$. Firststrand cDNA was synthesized from total RNA using a random hexamer primer (Promega, Madison, WI) following the manufacturer's instruction.

$P C R$. A 166 bp rat cDNA fragment was isolated from medial prefrontal cortex by differential display (N. Richtand, unpublished data). Using the BLASTN program on National Center for Biotechnology Information (NCBI) web server, we found that this fragment shared $81 \%$ identity to the mouse GIR (Harrigan et al., 1991). Then we designed two oligonucleotides (primer A and primer B) within the $166 \mathrm{bp}$ stretch and one oligonucleotide (MGIR1) in the transmembrane domain I of mouse GIR outside the $166 \mathrm{bp}$ rat-mouse matched region. The oligonucleotides were: primer A (5'-GCATAGACAGAGCCAAGGCCA-3', 1985-2005 bp, GenBank accession number AY029071), primer B (5'-AGCAGAGGCTGGTTCAGTCA-3', 1780-1799 bp, GenBank accession number AY029071), and MGIR1 (5'-CTCTTCGGTAATGTCCTGGTC-3', 537-557 bp, GenBank accession number M80481). Amplification was conducted with MGIR1 and primer A in a thermal cycler for 30 cycles of $94^{\circ} \mathrm{C}$ for $30 \mathrm{sec}, 50^{\circ} \mathrm{C}$ for $30 \mathrm{sec}$, and $68^{\circ} \mathrm{C}$ for 2 min using Platinum Taq polymerase (Life Technologies, Bethesda, MD). One-third of the RTPCR product was subjected to Southern blot analysis using the nested rat-specific primer $\mathrm{B}$ as probe. The blotted membrane was washed in $2 \times$ $\mathrm{SSC}$ at $60^{\circ} \mathrm{C}$ and exposed to Kodak X-Omat AR film at $-80^{\circ} \mathrm{C}$. The 1.4 kb PCR product, amplified from the prefrontal cortex and identified by Southern blot analysis, was purified by agarose gel electrophoresis and subcloned into the pGEM-T vector (Promega). Positive clones were selected by colony hybridization using primer $\mathrm{B}$ as probe again, and insert sequences were determined by DNA sequencing. Sequence analysis demonstrated a $97 \%$ sequence identity between the rat and mouse GIR cDNA (Harrigan et al., 1991).

5 '- and 3'-rapid amplification of cDNA ends. After obtaining the partial rat GIR cDNA, 5' - and 3'-rapid amplification of cDNA ends (RACE) was performed to determine the putative leading exon and $3^{\prime}$ noncoding region of rat GIR using the SMART RACE cDNA amplification kit (Clontech, Palo Alto, CA). Total RNA from rat prefrontal cortex was used as template to synthesize the first-strand cDNAs for $5^{\prime}$ - and $3^{\prime}$-ends following the manufacturer's instruction. The first-strand 5'-RACEready cDNA was synthesized with $5^{\prime}$-RACE cDNA synthesis primer (5'-CDS) and SMART II oligonucleotide, and the first-strand 3'-R ACEready cDNA was synthesized with $3^{\prime}-\mathrm{RACE}$ cDNA synthesis primer (3'-CDS) (Clontech).

The GIR-specific primers were designed from the obtained partial sequence of rat GIR: RGSP1 (5'-TTATAACAAGTGCTGCTCATGGCAAACCAGTGG-3', 1294-1326 bp, GenBank accession number AY029071), RNGSP1 (5'-CAAAGTAGAGGGCGTTGTTGGTGTGG3', 1264-1289 bp, GenBank accession number AY029071), RGSP2 (5'CCTCTTCGCTCTCTGCTGGTTCCCC-3', 1201-1225 bp, GenBank accession number AY029071), and RNGSP2 (5' -CAACTGCTATGTCCTCCTTCTGTCCAGC-3', 1228-1255 bp, GenBank accession number AY029071). The 5'-RACE amplification was performed in $50 \mu \mathrm{l}$ of final volume using $2.5 \mu \mathrm{l}$ of $1 / 100$ diluted $5^{\prime}$-R ACE-ready cDNA template, a
$2 \mu \mathrm{M}$ concentration of GIR-specific RGSP1 and Universal Primer Mix, and Advantage 2 Polymerase Mix (Clontech). The 3'-RACE amplification was performed similarly by using $3^{\prime}$-R ACE-ready cDNA and GIRspecific RGSP2. PCR amplification was conducted in a thermal cycler for initial five cycles of $94^{\circ} \mathrm{C}$ for $5 \mathrm{sec}$ and $72^{\circ} \mathrm{C}$ for $3 \mathrm{~min}$, followed by five cycles of $94^{\circ} \mathrm{C}$ for $5 \mathrm{sec}, 70^{\circ} \mathrm{C}$ for $10 \mathrm{sec}, 72^{\circ} \mathrm{C}$ for $3 \mathrm{~min}$, and ended with 35 cycles of $94^{\circ} \mathrm{C}$ for $5 \mathrm{sec}, 68^{\circ} \mathrm{C}$ for $10 \mathrm{sec}$, and $72^{\circ} \mathrm{C}$ for $3 \mathrm{~min}$. The RACE amplification products were confirmed by Southern blot analysis with nested GIR-specific oligonucleotides RNGSP1 for 5'-RACE product, and RNGSP2 for 3'-RACE product, respectively. The positive DNA fragments were gel-purified and subcloned into the pGEM-T vector (Promega). Positive clones were selected and subjected to DNA sequencing.

Direct DNA sequencing. Plasmid DNA was prepared using a Qiagen (Valencia, CA) DNA purification kit. Double-stranded DNA was directly sequenced at the University of Cincinnati DNA Core Facility and confirmed by complementary strand sequence.

Tissue distribution. Tissue-specific expression of GIR was investigated by Northern blot analysis. A rat multiple-tissue Northern blot of poly $(\mathrm{A})^{+}$RNA from heart, brain, spleen, lung, liver, skeletal muscle, kidney, and testis was purchased from Clontech. The rat GIR-specific cDNA probe (1201-1568 bp, GenBank accession number AY029071) was labeled by random priming with $\left[\alpha^{-32} \mathrm{P}\right] \mathrm{dCTP}$ and incubated with the membrane at $68^{\circ} \mathrm{C}$ for $1 \mathrm{hr}$ in ExpressHyb Solution (Clontech). The blot was washed once with $2 \times$ SSC containing $0.05 \%$ SDS at room temperature for $40 \mathrm{~min}$ and twice with $0.1 \times \mathrm{SSC}$ containing $0.1 \%$ SDS at $50^{\circ} \mathrm{C}$ for $40 \mathrm{~min}$, followed by exposure to Kodak X-Omat AR film at $-80^{\circ} \mathrm{C}$. Finally, the blot was stripped and rehybridized with a rat $\beta$-actin cDNA probe (Clontech) as an internal standard.

In situ hybridization. Assessment of GIR mRNA expression was accomplished using probes that recognize the $368 \mathrm{bp}$ stretch of GIR mRNA (complementary to the 1201-1568 bp region of rat GIR mRNA, GenBank accession number AY029071). Labeling reactions included 60 $\mu \mathrm{Ci}$ of ${ }^{35} \mathrm{~S}$-UTP (specific activity $1800 \mathrm{Ci} / \mathrm{mmol}$ ), $1 \times$ transcription buffer, $15 \mathrm{mM}$ dithiothreitol, $200 \mu \mathrm{M}$ GTP, CTP, and ATP, $10 \mu \mathrm{M}$ UTP, $40 \mathrm{U}$ of placental RNase inhibitor, $1 \mu \mathrm{g}$ of linearized plasmid DNA, and $20 \mathrm{U}$ of appropriate RNA polymerase (T3 or T7; Roche Molecular Biochemicals, Indianapolis, IN). Reactions were incubated at $37^{\circ} \mathrm{C}$ for 90 min. The DNA template was then removed by RNase-free DNase I digestion for $15 \mathrm{~min}$ at $37^{\circ} \mathrm{C}$, and reaction mix was diluted to $100 \mu \mathrm{l}$ with diethylpyrocarbonate (DEPC)-treated water and ethanol precipitated with $7.5 \mathrm{M}$ ammonium acetate.

Brain sections were fixed for $10 \mathrm{~min}$ in $4 \%$ buffered paraformaldehyde and rinsed twice in $5 \mathrm{~mm}$ DEPC-treated potassium PBS (KPBS), $\mathrm{pH} 7.5$ ( $5 \mathrm{~min}$ ), twice in KPBS and $0.2 \%$ glycine, and twice in KPBS. Sections were then acetylated by a 10 min treatment with $0.25 \%$ acetic anhydride and $0.1 \mathrm{M}$ triethanolamine, $\mathrm{pH} 8.0$, rinsed twice in $0.2 \times \mathrm{SSC}(5 \mathrm{~min})$, and dehydrated in a graded ethanol series. Labeled probes were added to a hybridization buffer containing $50 \%$ formamide, $20 \mathrm{~mm}$ Tris- $\mathrm{HCl}, \mathrm{pH}$ 7.5, $1 \mathrm{~mm}$ EDTA, $335 \mathrm{~mm} \mathrm{NaCl}, 1 \times$ Denhardt's solution, $200 \mu \mathrm{g} / \mathrm{ml}$ salmon sperm DNA, $150 \mu \mathrm{g} / \mathrm{ml}$ yeast transfer RNA, $20 \mathrm{~mm}$ dithiothreitol, and $10 \%$ dextran sulfate. Probes were denatured for $15 \mathrm{~min}$ at $65^{\circ} \mathrm{C}$ and $50 \mu \mathrm{l}\left(1 \times 10^{6} \mathrm{cpm}\right)$ of diluted probe applied to each slide. Slides were coverslipped, placed in moistened chambers, and incubated overnight at $55^{\circ} \mathrm{C}$. After hybridization, coverslips were removed in $0.2 \times$ SSC and rinsed in fresh $0.2 \times$ SSC for $10 \mathrm{~min}$. Sections were treated with RNase A $(50 \mu \mathrm{g} / \mathrm{ml})$ for $30 \mathrm{~min}$ at $37^{\circ} \mathrm{C}$ and transferred to fresh $2 \times \mathrm{SSC}$, then rinsed three times in $0.2 \times$ SSC $(10$ min per wash) followed by a $1 \mathrm{hr}$ wash in $0.2 \times \mathrm{SSC}$ at $65^{\circ} \mathrm{C}$. Sections were dehydrated in a graded ethanol series, dried at room temperature, and exposed for 14-21 d to Kodak BioM AX film (Eastman Kodak, Rochester, NY). Hybridization controls included (1) sections hybridized with sense-strand probe generated from the same vector construct, and (2) sections preincubated in RNase A (50 $\mu \mathrm{g} / \mathrm{ml}, 30 \mathrm{~min}, 37^{\circ} \mathrm{C}$ ) before hybridization with antisense probe. No hybridization signal was observed after either control procedure.

GIR $m R N A$ expression after chronic amphetamine administration. Male Sprague Dawley rats (200-250 gm; Harlan Sprague Dawley Laboratories) received subcutaneous injections of either D-AMPH $(2.5 \mathrm{mg} / \mathrm{kg})$ or saline $(1 \mathrm{ml} / \mathrm{kg})$ in their home cages once daily for 5 consecutive days (days 1-5). On day 9, $4 \mathrm{~d}$ after completion of this pretreatment regimen, all animals were transferred to residential activity chambers (Segal and Kuczenski, 1987; Richtand et al., 2000) and received saline injection (1 $\mathrm{ml} / \mathrm{kg}$ ) on days 10 and 11 to measure conditioned response to injection. On day $12,7 \mathrm{~d}$ after completion of the pretreatment regimen, all rats received D-AMPH $(2.5 \mathrm{mg} / \mathrm{kg})$, and locomotor activity was determined 


\section{Kyte/Doolittle Hydrophilicity:}

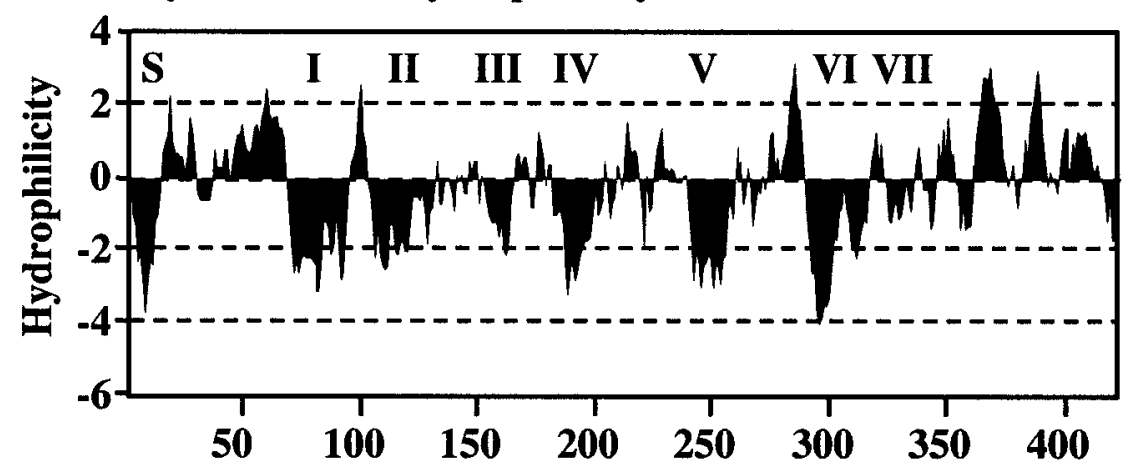

Amino acid number
Figure 1. Hydropathy analysis. Plot of hydrophobicity and hydrophilicity of the rat GIR protein. Eight hydrophobic domains, including a putative signal sequence $(S)$ and seven transmembrane spans $(I-V I I)$ are predicted. by photobeam monitoring for $150 \mathrm{~min}$ after injection. Locomotor activity is expressed as crossovers, defined as the number of times the animal crosses into any of four quadrants subdividing the enclosure. All animals were killed by decapitation $4 \mathrm{hr}$ after injection, and total RNA was extracted from prefrontal cortex for determination of GIR mRNA expression. In a separate experiment, rats were injected with either D-AMPH $(2.5 \mathrm{mg} / \mathrm{kg})$ or saline $(1 \mathrm{ml} / \mathrm{kg})$ for 5 consecutive days and killed by decapitation $7 \mathrm{~d}$ after the last injection without the final AMPH challenge. Thus, four groups were generated: SAL-AMPH (saline for $5 \mathrm{~d}$ and AMPH at challenge), AMPH-AMPH (AMPH for $5 \mathrm{~d}$ and AMPH at challenge), SAL (Saline for $5 \mathrm{~d}$ ), and AMPH (AMPH for $5 \mathrm{~d}$ ).

Construction of competitor DNA and quantitative RT-PCR. To construct the mutant template for competitive PCR, a 20 bp GIR sequence (5'-TCGCTCTCTGCTGGTTCCCC-3', 1206-1225 bp, GenBank accession number AY029071) was incorporated into the $5^{\prime}$ end of the upstream PCR primer so that a rat GIR cDNA fragment could be amplified by RT-PCR using the chimeric upstream primer $\left(5^{\prime}-T C G C T C T C T G C T\right.$ GGTTCCCCTCCCTTCATCTACTGCTGGC-3', 1327-1346 bp, GenBank accession number AY029071) and the downstream primer (5'CGGCCACAGTGGGTTCCAC-3', 1550-1568 bp, GenBank accession number AY029071). The 262 bp PCR product was subcloned into the pGEM-T vector (Promega). The plasmid DNA was purified (Qiagen), and the competitor insert was verified by DNA sequencing. The insert (262 bp) was released by EcoRI digestion and purified by agarose gel electrophoresis. DNA concentration was determined spectrophotometrically. Serial dilutions of mutant template were prepared.

The amount of GIR mRNA was quantitated by competitive RT-PCR as described previously (Siebert and Larrick, 1992; Raeymaekers, 1999). Briefly, reverse transcription was performed with $2 \mu \mathrm{g}$ of total RNA using a nonspecific random hexamer primer (Promega). One microliter of first-strand cDNA was mixed with known amounts of linearized competitor DNA ranging from 0.5 to 16 fg and subjected to coamplification with GIR-specific primers (5'-TCGCTCTCTGCTGGTTCCCC3', 1206-1225 bp and 5'-CGGCCACAGTGGGTTCCAC-3', 1550-1568 $\mathrm{bp}$, GenBank accession number AY029071). PCR was run for 30 cycles of $94^{\circ} \mathrm{C}$ for $1 \mathrm{~min}, 60^{\circ} \mathrm{C}$ for $50 \mathrm{sec}$, and $72^{\circ} \mathrm{C}$ for $1.5 \mathrm{~min}$, and the PCR products were electrophoresed on $1.2 \%$ agarose gel and stained with ethidium bromide. The amount of rat GIR mRNA was determined by calculating how much of the competitor was required to achieve equal molar amounts of products as described previously (Siebert and Larrick, 1992; Raeymaekers, 1999). To do so, the intensities of ethidium bromide fluorescence bands, corresponding to the PCR products either from the GIR mRNA or from the competitor (101 bp size difference), were measured densitometrically on the computer imaging of the gels. The quantitative determination was achieved by digitization of gels with a BioImage System Quantity One (Bio-Rad, Hercules, CA) and further densitometric evaluation with the ImageQuant 1.2 software. The intensity ratios between the two bands were logarithmically plotted against the known initial input of competitor template, and the amount of GIR mRNA in the total RNA samples was calculated by extrapolating from the intersection of the curves, where the amounts of target and competitor are equal $(\log 10=0)$ to the $x$-axis, as indicated by Siebert and Larrick (1992). Control PCR with water or RNA template without reverse transcription gave no amplification product (data not shown).

Statistical analysis. Group data are expressed as mean \pm SEM. Statis- tical analysis was performed by unpaired Student's $t$ test. Differences were considered significant at $p<0.05$.

\section{RESULTS}

\section{Identification and characterization of rat GIR cDNA}

We have cloned and characterized the full-length GIR cDNA from rat prefrontal cortex by RT-PCR, 5'-RACE, and $3^{\prime}$-R ACE. Complete sequencing of the cDNA reveals a 1266 bp open reading frame flanked by a 307 bp 5'-untranslated region and a 2100 bp 3'-untranslated region (GenBank accession number AY029071). A polyadenylation signal is present at position 3615, 16 nucleotides upstream of the poly $(\mathrm{A})$ tail. A potential translation initiation site (ATG) is assigned to the methionine codon at nucleotide positions $308-310$ because it matches the vertebrate consensus sequences at +4 position and is predicted to initiate translation of GIR, although it shows a suboptimal sequence at the -3 position (Kozak, 1991).

\section{Amino acid sequence and its comparison with other receptors}

Based on amino acid sequence derived from the rat GIR cDNA, this gene encodes a protein of 422 amino acids with a relative molecular mass of $48 \mathrm{kDa}$. The hydrophobicity plot of the protein sequence reveals the presence of seven distributed hydrophobic regions throughout the polypeptide, indicating that GIR belongs to the G-protein-coupled receptor superfamily (Fig. 1). The seven putative transmembrane $\alpha$-helices of GIR consist of a continuous stretch of 17-23 uncharged amino acid residues, except that transmembrane domains II, III, and IV contain Asp116, His155, Asp167, and His203, respectively (Fig. 2A). Both Figures 1 and $2 A$ show the hydrophobic $\mathrm{N}$-terminal region with the presence of a potential signal sequence (17 residue in length) and potential signal peptidase cleavage sites (von Heijne, 1986) located at Val15 and Ala17.

The primary amino acid sequence of rat GIR was blasted in the GenBank database, and revealed a significant similarity to other G-protein-coupled receptors (Fig. 2A). Overall, the rat GIR shares the highest sequence identities with mouse (97\%) and human GIR (88\%) and limited but close identities with rat substance $\mathrm{P}$ receptor (NK-1R, 33.7\%), neurokinin A receptor (NK-2R, 31.3\%), and neurokinin B receptor (NK-3R, 34.3\%). The rat GIR shows sequence identities to the transmembrane domains I (50\%), II (38\%), III (27\%), IV (33\%), V (36\%), VI $(43 \%)$, and VII $(70 \%)$ of substance P receptor, with an overall identity of $42.4 \%$ in the transmembrane domain regions. It also 
Figure 2. Amino acid sequence of rat GIR and its comparison with other receptors. $A$, The amino acid sequences of rat GIR, mouse GIR, human GIR, rat substance $\mathrm{P}$ receptor $(N K 1 R)$, rat neurokinin $\mathrm{B}$ receptor $(N K 3 R)$, and rat neurokinin A receptor $(N K 2 R)$ are aligned for best homology. Transmembrane domains $(T M)$ of the rat GIR are predicted and labeled. Signal peptide is predicted and boxed. $\mathbf{\Delta}$ indicates potential glycosylation sites, - indicates potential protein kinase $\mathrm{C}$ phosphorylation sites, and $\bigcirc$ indicates potential protein kinase A phosphorylation sites. a indicates Cys residues, * indicates Asp residues, and $\wedge$ indicates His residues. $B$, Relatedness of GIR to other members of the seven transmembrane receptor family. A dendrogram was constructed by Pileup (GCG program) of the amino acid sequences representing the cloned members of the seven transmembrane family receptors (TSHR, thyrotropin receptor; $L H R$, lutropin receptor; NY4R, neuropeptide Y4 receptor; $N Y 1 R$, neuropeptide Y1 receptor; GIR, glucocorticoid-induced receptor; NK1R, substance $\mathrm{P}$ receptor; $N K 3 R$, neurokinin $\mathrm{B}$ receptor; $N K 2 R$, neurokinin A receptor; $O P R K$, Kapp-type opioid receptor; $D 3 R$, dopamine D3 receptor; $D 2 R$, dopamine $\mathrm{D} 2$ receptor; $D 5 R$, dopamine $\mathrm{D} 5$ receptor; $D 1 R$, dopamine D1 receptor; $\beta 2 A R$, adrenergic $\beta 2$ receptor; $\beta 1 A R$, adrenergic $\beta 1$ receptor; STE2, yeast $\alpha$ factor receptor).

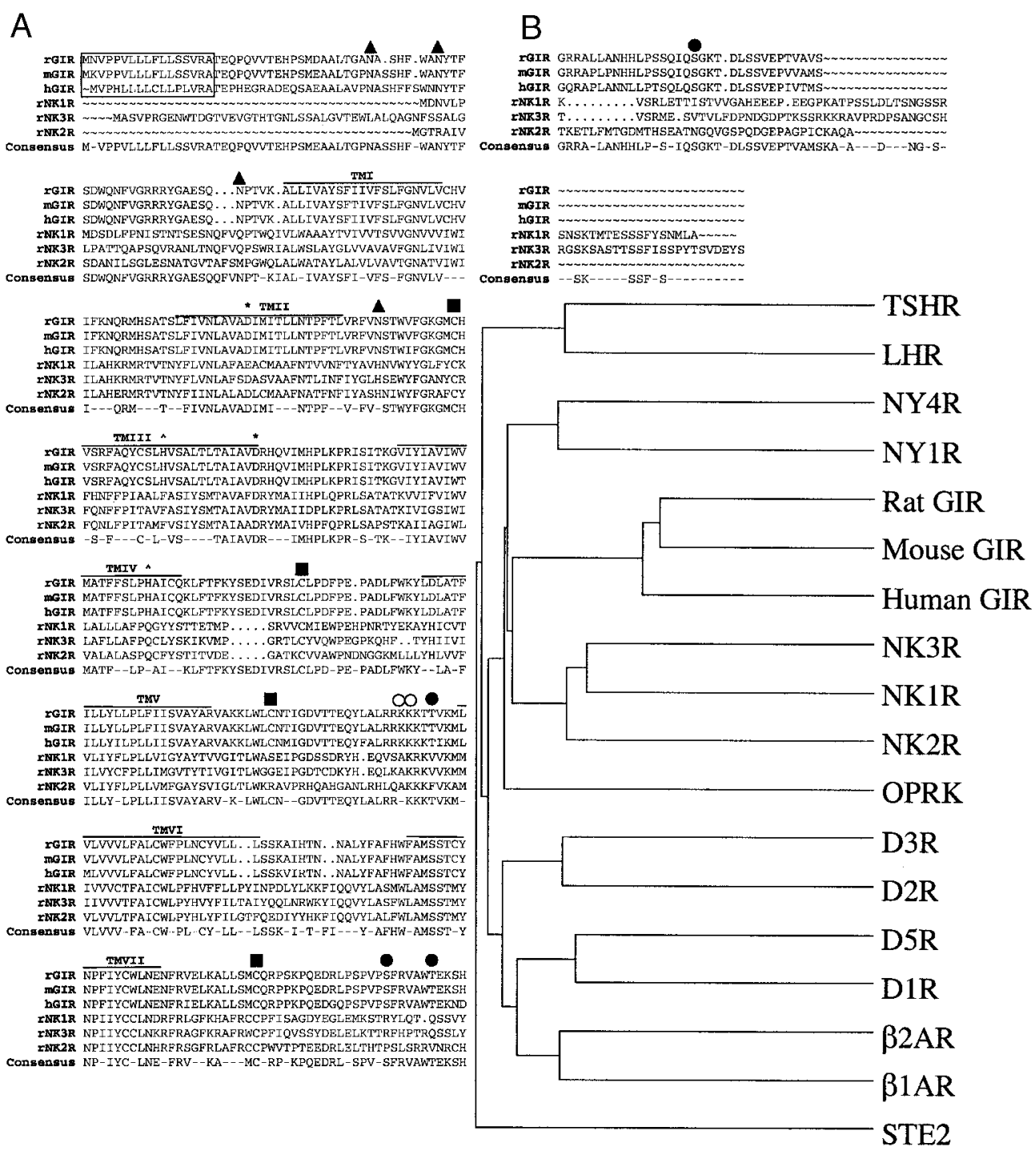

shows significant sequence identities to the first (33\%), second $(53 \%)$, and third intracellular loops $(31 \%)$, with more limited sequence identities to the $\mathrm{N}$ terminus $(22 \%)$, first $(25 \%)$, second $(27 \%)$, and third extracellular loops $(8 \%)$ as well as the $\mathrm{C}$ terminus $(20 \%)$ of substance $\mathrm{P}$ receptor. Figure $2 A$ shows the alignment of these receptors illustrating several conserved regions in their amino acid sequences. The rat GIR has several structural characteristics common to the members of the G-protein-coupled receptor superfamily. Four potential N-linked glycosylation sites are identified as Asn38, Asn45, Asn66, and Asn133 according to the consensus sequence of Asn-X-Ser/Thr. Three of them are located in the $\mathrm{N}$ terminus, and one is in the first extracellular loop. Several consensus sites for possible phosphorylation by protein kinase $\mathrm{C}$ and protein kinase $\mathrm{A}$ exist in the third intracellular loop and $\mathrm{C}$ terminus, respectively. Several cysteine residues are identified in the intracellular and extracellular loops as well as $\mathrm{C}$ terminus, respectively. In comparison with the mouse GIR, the rat GIR has a deletion involving one amino acid residue at position 40 in the $\mathrm{N}$ terminus. A dendrogram was constructed using the Wisconsin Package version 10, Genetics Computer Group (GCG, Madison, WI), and the clusters of GIR and tachykinin receptors are closely related as compared with the other members in the G-protein-coupled receptor superfamily (Fig. 2B).

\section{Tissue distribution of rat GIR}

The tissue distribution of GIR expression in rats was examined by Northern blot analysis. A major mRNA species was detected in brain by Northern blot analysis using rat GIR cDNA as probe (Fig. 3). The expression was not detected in peripheral tissues, including heart, spleen, lung, liver, skeletal muscle, kidney, and testis (Fig. 3).

\section{Regional localization of GIR mRNA in rat forebrain}

In situ hybridization analysis was performed to assess GIR mRNA expression in rat forebrain (Figs. 4, 5, Table 1). Hybridizations revealed high levels of GIR expression in scattered hippocampal neurons (Fig. $4 A$ ), the nucleus of the lateral olfactory tract (Fig. $4 B$ ), and midline thalamic nuclei (nucleus reuniens of the thalamus, zona incerta) (Fig. $4 C$ ). Positive signal was also observed in the dorsolateral septum and tenia tecta. Significant hybridization signal was also observed in all regions of neocortex and in limbic cortical regions, notably including infralimbic, prelimbic, and anterior cingulate regions comprising the rodent prefrontal cortical system (Fig. 4D,E). Significant positive hybridization was also observed in the olfactory bulbs, posterior divisions of the bed nucleus of the stria terminalis, and the ventromedial and ventrobasal complexes of the thalamus. Low levels of 


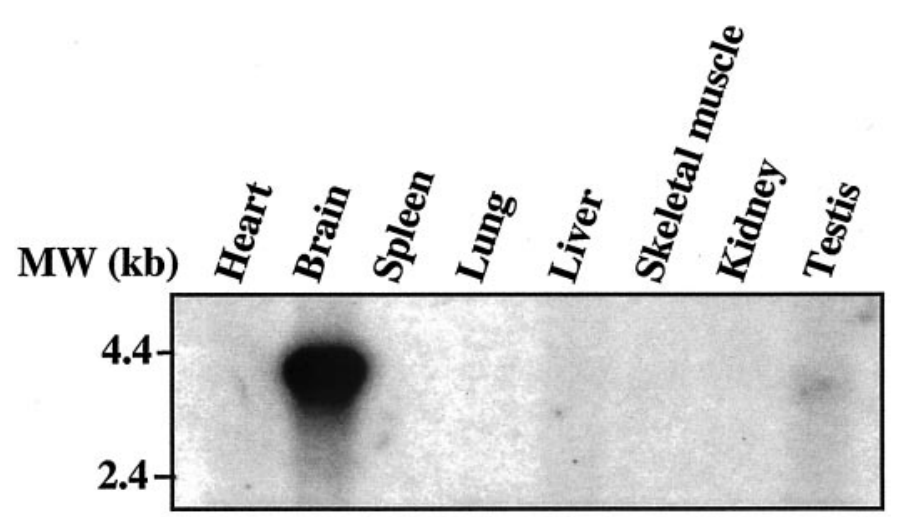

Rat GIR

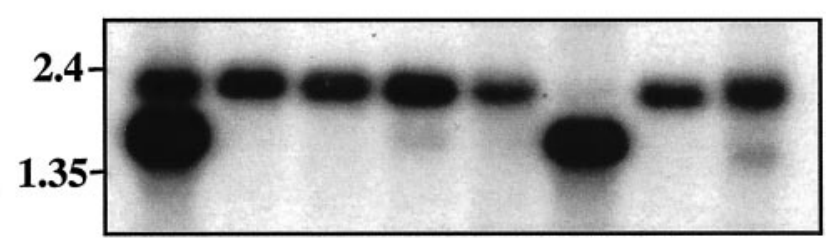

$\beta$-actin

Figure 3. Expression of GIR in adult rat tissues by Northern blot analysis. Poly(A) ${ }^{+}$RNA $(2 \mu \mathrm{g})$ from various rat tissues was hybridized with probes specific to rat GIR (top panel) and $\beta$-actin (bottom panel) on a nylon membrane. The origin of each RNA is shown at the top, and the molecular mass of standard markers (in kilobases) is shown on the left. GIR expression is detected in brain. No detectable hybridization signal is seen in heart, spleen, lung, liver, skeletal muscle, kidney, and testis. The blot was stripped and rehybridized with a $\beta$-actin probe.

GIR mRNA could be detected in neuroendocrine regulatory regions of the hypothalamus, including the medial preoptic area, paraventricular nucleus, supraoptic nucleus, and suprachiasmatic nucleus. Low but definitely detectable levels of GIR mRNA were observed in the nucleus accumbens shell (Fig. 5). In no case was positive hybridization observed in sections hybridized with sensestrand probes or sections pretreated with RNaseA.

Notably, GIR mRNA expression in the caudate putamen was confined to widely scattered neurons (Fig. $4 F$ ), and expression in nucleus accumbens was quite weak and limited to the shell region. This distribution stands in marked contrast to anatomical localization of GIR mRNA in mouse, which showed rich expression throughout the striatum and nucleus accumbens using the same rat cRNA probe (Fig. 5, compare $A, B$ ).

\section{Response of rat GIR expression to chronic amphetamine administration}

Because of longstanding neurochemical changes in prefrontal cortex after repetitive AMPH (Hamamura and Fibiger, 1993) and abundant GIR expression in this brain region (Fig. 4D,E), we determined the effect of amphetamine on GIR expression in this brain region after chronic amphetamine administration. The expression levels of GIR mRNA in rat prefrontal cortex after behavioral sensitization to amphetamine were quantitatively determined by competitive RT-PCR. The representative competitive PCR image is shown in Figure $6 A$. The GIR mRNA levels were calculated from the linear regression plot of the ratio plotted logarthmically against the initial input of competitor DNA, as shown in Figure $6 B$. In the experiment with amphetamine ad- ministration for $5 \mathrm{~d}$ followed by a challenge injection $7 \mathrm{~d}$ after drug ceased, the GIR mRNA levels in prefrontal cortex of AM$\mathrm{PH}-\mathrm{AMPH}$ rats were significantly increased by 1.31 -fold compared with SAL-AMPH rats $(2.97 \pm 0.26$ vs $2.27 \pm 0.22 \mathrm{fg} / 100$ ng total RNA; $n=6 ; p<0.05$ ) (Fig. $6 B$ ). Animal behavior was also determined following this amphetamine treatment regimen. In agreement with earlier studies (Segal and Kuczenski, 1994), amphetamine pretreatment resulted in robust behavioral sensitization under these conditions, as evidenced by the significant decrease in locomotion of AMPH-AMPH rats at 12-60 min after injection during the focused stereotypy phase of AMPH response $(50.20 \pm 12.63$ vs $286.00 \pm 27.57$ crossovers $/ 12-60 \mathrm{~min}$; $n=6 ; p<0.0001)$ and increased locomotion at 60-150 min during the post-stereotypy locomotion phase of AMPH response $(496.67 \pm 70.28$ vs $312.25 \pm 29.17$ crossovers $/ 60-150 \mathrm{~min} ; n=6$; $P<0.05$ ) (Fig. 6C).

In a separate experiment with chronic amphetamine exposure but no challenge injection, the expression levels of GIR were quantitatively determined by competitive RT-PCR $7 \mathrm{~d}$ after an identical $5 \mathrm{~d}$ pretreatment regimen with amphetamine or saline. A similar upregulation of GIR mRNA was observed $7 \mathrm{~d}$ after amphetamine ceased. The GIR mRNA levels in prefrontal cortex of AMPH rats were significantly increased by 1.70 -fold compared with SAL rats $(3.65 \pm 0.22$ vs $2.15 \pm 0.33 \mathrm{fg} / 100 \mathrm{ng}$ total RNA; $n=6 ; p<0.05$ ) (Fig. 6D).

\section{DISCUSSION}

We have identified a stress-responsive receptor, GIR, from prefrontal cortex of rat brain. The deduced amino acid sequence suggests that GIR is a member of the G-protein-coupled receptor superfamily and shares the identity to tachykinin receptors (31$34 \%$ ). GIR is expressed preferentially in the brain and has demonstrated a responsive alteration on gene expression to amphetamine treatment. Moreover, the increased levels of GIR mRNA persist $7 \mathrm{~d}$ after withdrawal from chronic amphetamine administration. Regulation of GIR mRNA expression may represent a long-lasting effect at the molecular level in neuroadaptation to psychostimulants.

The structural analysis of rat GIR, a G-protein-coupled receptor, suggests some important clues to its potential pharmacological and physiological functions. The putative protein kinase $\mathrm{C}$ site and protein kinase A sites in the third intracellular loop are often called the "G-protein-loop" because of their importance in G-protein coupling (Strader et al., 1994), suggesting that phosphorylation may modulate the functional activity of GIR. The role of putative protein kinase $\mathrm{C}$ sites in the $\mathrm{C}$ terminus of rat GIR remains to be studied because similar phosphorylation sites in the $\mathrm{C}$ terminus of $\beta$-adrenergic receptor have been shown to play a pivotal role in regulating receptor desensitization (Bouvier et al., 1989; Clark et al., 1989). Similar to the $\beta$-adrenergic receptor, a potential disulfide bond linking Cys143 in the first extracellular loop and Cys223 in the second extracellular loop of rat GIR may help to maintain the active conformation of the receptor and is important for ligand receptor interaction (Dohlman et al., 1990). The highly conserved Cys362 in the $\mathrm{C}$ terminus of rat GIR may function as a target site for palmitoylation, and the palmityl group may anchor the cytoplasmic tail of the receptor to the plasma membrane to control the structure of this receptor (O’Dowd et al., 1989; Strader et al., 1994).

Rat GIR is an orphan receptor, however, it shows close sequence identity to the rat substance $\mathrm{P}$ receptor $(33.7 \%)$ with divergent similarity in different regions. For example, the most 

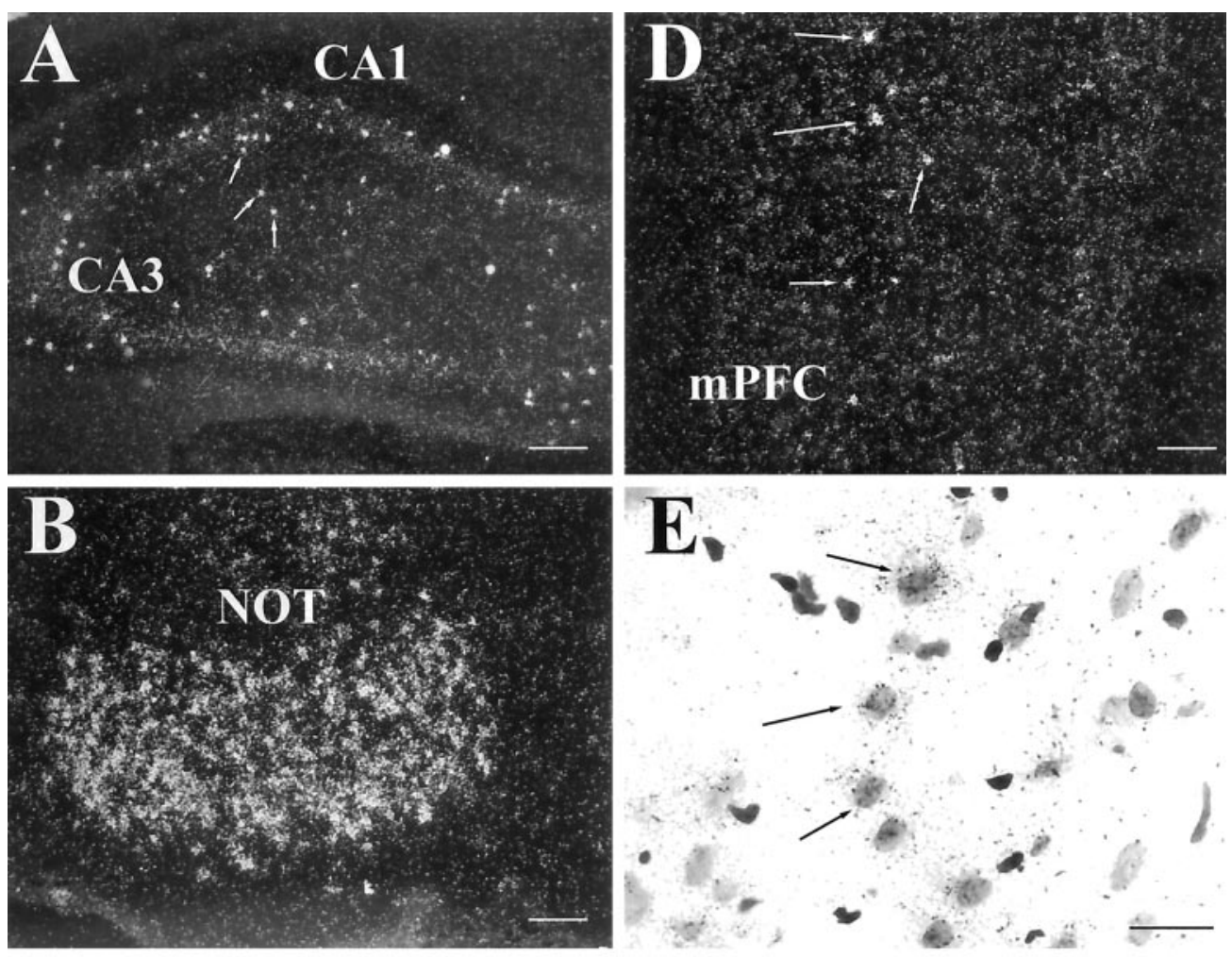

Figure 4. Expression of GIR mRNA in the forebrain of the rat $(A-F) . A$, GIR mRNA is expressed in scattered neurons throughout the hippocampal formation. $B$, The highest levels of GIR mRNA are detected in the nucleus of the lateral nucleus of the olfactory tract $(N O T)$. C, Signal is also observed in several diencephalic nuclei, including the anteromedial thalamic nucleus and nucleus reuniens. $D$, Dense GIR mRNA expression is observed in scattered cells of the cerebral cortex, including the medial prefrontal region. E, High-power photomicrograph of prefrontal cortex GIR hybridization, illustrating confinement of grains to neuronal nuclei (arrows). $F$, Localization of GIR mRNA in caudate putamen; weak labeling is observed in widely scattered cells throughout the structure. Scale bars: $A, B, D, F$, $100 \mu \mathrm{m} ; C, 200 \mu \mathrm{m} ; E, 25 \mu \mathrm{m}$.
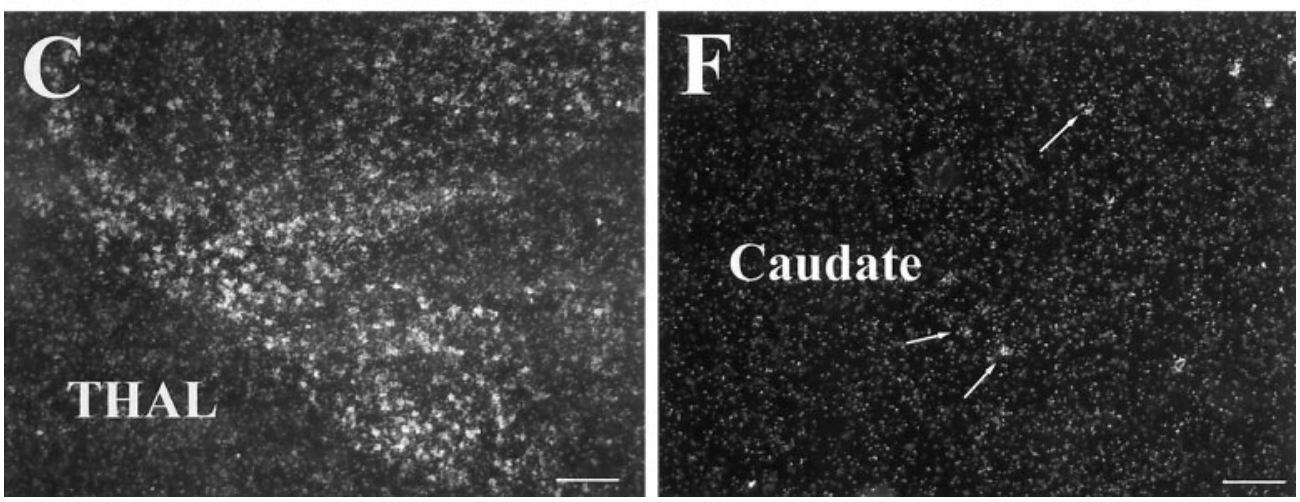

conserved portions of these two receptors are the transmembrane domain I (50\%), the second intracellular loop (53\%), and the transmembrane domain VII $(70 \%)$, and the least conserved is the third extracellular loop (8\%). Although the endogenous ligand for GIR is unknown, the primary sequence identity between GIR and substance $\mathrm{P}$ receptor in the transmembrane segments $(42.4 \%$ overall) suggests that GIR may be a member of the same subfamily as substance P receptor (Strader et al., 1994). Construction of a dendrogram supports the notion that GIR may belong to the peptide receptor subfamily (e.g., substance $\mathrm{P}$ receptor), with more distant relationship to the subfamilies of glycoprotein hormone receptors (e.g., thyrotropin receptor) and biogenic amine receptors (e.g., dopamine receptor) (Strader et al., 1994). Notably there is a conserved Asp residue (Asp167 in rat GIR) on the edge of the transmembrane domain III of GIR, which is seen as well in substance P, neurokinin B, and neurokinin A receptors. Because the highly conserved Asp residue in the transmembrane domain III has only been reported for the biogenic amine receptors with a primary function of interacting with the biogenic amines (Strader et al., 1987, 1994), the potential role of this region in determining ligand specificity in the peptide receptor subfamily should be investigated. The Asp116 residue, found in the transmembrane domain II of rat GIR, is conserved in G-proteincoupled receptors and appears to be involved in transduction of the agonist-binding signals to stimulate an interaction with the appropriate G-protein (Strader et al., 1994).

The dominant expression of GIR occurs in brain, which agrees with findings for both mouse and human GIR mRNA expression (Harrigan et al., 1991; Parker et al., 2000). Within brain, GIR mRNA is expressed neuronally, as demonstrated by in situ hybridization with intense staining localized to nucleus of the lateral olfactory tract, hippocampus, neocortex, and limbic cortical regions. Of particular interest, very high levels of GIR mRNA were observed in the nucleus of the lateral olfactory tract, responsible for relay of olfactory information to piriform cortex and amygdala. High levels of GIR were also observed in the midline thalamic nuclei and in dorsolateral septum, which have reciprocal connections with limbic cortex and hippocampus, and in the hippocampus itself, a critical component of learning and memory integration (Jakab and Leranth, 1995; Price, 1995; Shipley et al., 1995). Positive hybridization signal was also observed in limbic cortical structures, including the infralimbic, prelimbic, and ante- 


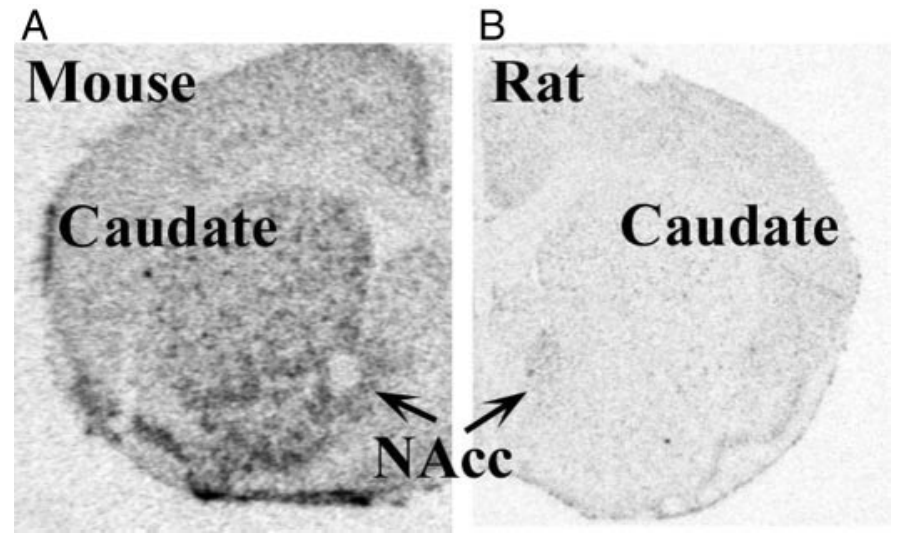

Figure 5. Expression of GIR mRNA in caudate nucleus and nucleus accumbens of mouse $(A)$ and rat $(B)$. The same probe was used for panels $A$ and $B$. $A$, Note extensive GIR mRNA in the caudate putamen ( $\mathrm{Cau}$ date) and nucleus accumbens (NAcc) of the mouse. $B$, Weak, but positive hybridization signal is observed in the shell of the nucleus accumbens (NAcc). No signal is observed in the caudate putamen (Caudate) at this magnification.

rior cingulate cortices, as well as the limbic (shell) region of the nucleus accumbens. Together, these data suggest a prominent role for GIR in limbic circuits regulating memory, stress, and reward.

Expression of GIR mRNA is also observed in forebrain effector systems mediating anxiety and neuroendocrine control. The bed nucleus of the stria terminalis is involved in coordinating behavioral and neuroendocrine responses to fearful stimuli (Henke, 1984; Casada and Dafny, 1991; Gray et al., 1993). The preoptic area, arcuate nucleus, paraventricular nucleus, and supraoptic nucleus are involved in neuroendocrine and autonomic nervous system integration (Swanson, 1987). As such, GIR circuitry may modulate behavioral and physiological interpretation of environmental information at the level of both associative and effector systems.

The expression of GIR mRNA is marked by a pronounced species difference between mouse and rat (Pesini et al., 1998). Most notable is the differential distribution of GIR in striatum and cortex. In mouse, GIR is highly expressed in targets of the nigrostriatal and mesolimbic dopamine system, including the neostriatum, nucleus accumbens, and olfactory tubercle. This finding suggests that in mouse, GIR may play a role in modulation of dopaminergic neurotransmission. The lack of GIR transcripts in the nucleus of the lateral olfactory tract, ventral thalamus, and cortex suggests a less pronounced involvement of this receptor in aspects of limbic integration in murine species. However, GIR is highly expressed in hippocampus of both species, allowing for a similar role of this receptor in modulating hippocampal function.

The persistent upregulation of GIR mRNA found in amphetamine-sensitized rat brain long after drug discontinuation is of importance because the regulation of gene expression is believed to be the molecular basis for stable neuroadaptation to chronic drug exposure (Nestler, 2000). In contrast to transient gene alterations, the persistent gene alterations are responsible for maintenance and expression of behavioral sensitization (White and Kalivas, 1998). Although extensive efforts have been made to search for candidate genes for stable neuroadaptation, only $\Delta$ FosB and NAC- 1 have been reported to be persistently altered in nucleus accumbens after drug discontinuation (Cha et al., 1997; Kelz et al., 1999; Kelz and Nestler, 2000). In a similar

\begin{tabular}{|c|c|c|}
\hline Region & $\begin{array}{l}\text { Labeling } \\
\text { intensity }\end{array}$ & Comments \\
\hline \multicolumn{3}{|l|}{ Telencephalon: } \\
\hline Neocortex & ++ & Scattered cells \\
\hline \multicolumn{3}{|l|}{ Limbic cortex } \\
\hline Infralimbic & ++ & Scattered cells \\
\hline Cingulate & ++ & Scattered cells \\
\hline Prelimbic & ++ & Scattered cells \\
\hline \multicolumn{3}{|l|}{ Olfactory system } \\
\hline Piriform cortex & ++ & \\
\hline Nucleus of the lateral olfactory tract & +++ & \\
\hline Olfactory bulb & +++ & \\
\hline \multicolumn{3}{|l|}{ Hippocampus } \\
\hline CA1 & $++/+++$ & Scattered cells \\
\hline CA3 & $++/+++$ & Scattered cells \\
\hline Dentate gyrus & $++/+++$ & Scattered cells \\
\hline \multicolumn{3}{|l|}{ Septum } \\
\hline Dorsolateral septal n. & ++ & \\
\hline Tenia tecta & +++ & \\
\hline \multicolumn{3}{|l|}{ Striatum } \\
\hline Caudate putamen & $+/-$ & \\
\hline Nucleus accumbens core & - & \\
\hline Nucleus accumbens shell & + & \\
\hline \multicolumn{3}{|l|}{ Diencephalon } \\
\hline Zona incerta & +++ & \\
\hline \multicolumn{3}{|l|}{ Thalamus } \\
\hline Nucleus reuniens & ++ & \\
\hline Anteromedial n. & +++ & \\
\hline Anterodorsal n. & ++ & \\
\hline Ventrolateral n. & + & \\
\hline Ventromedial n. & + & \\
\hline \multicolumn{3}{|l|}{ Hypothalamus } \\
\hline Medial preoptic area & + & \\
\hline Paraventricular n., magnocellular div. & + & \\
\hline Paraventricular n., parvocellular div. & + & \\
\hline Arcuate $n$ & + & \\
\hline
\end{tabular}

- , No expression evident; +/-, weak expression in widely scattered cells; + , low expression ( $<10$ grains per cell above background or diffuse hybridization signal over the entire structure); ++ , intermediate expression (10-25 grains per cell or intermediate hybridization signal across the region); +++ , high expression $(>25$ grains per cell or intense hybridization over the entire structure). Scattered cells indicate that the observed hybridization signal was seen in scattered neurons throughout the structure, rather than being restricted to pyramidal or granule cell layers (suggestive of interneurons).

manner, GIR mRNA is also increased after chronic exposure to amphetamine. Importantly, once induced, this increased GIR mRNA expression persists in brain for at least $7 \mathrm{~d}$ after amphetamine withdrawal. The sustained GIR mRNA upregulation is correlated with behavioral sensitization, as observed by increased locomotor activity and augmented stereotyped motion. Because prefrontal cortex is known to be critical in the induction of behavioral sensitization leading to increased locomotor activity (Wolf et al., 1995; Kalivas and Nakamura, 1999), a persistent modulation of GIR expression may be involved in the stable neuroadaptation to drugs of abuse.

One possible mechanism for amphetamine-induced GIR mRNA upregulation could be the transcriptional regulation involving nuclear transcription factors or steroid hormones. Behavioral sensitization to amphetamine is accompanied by an en- 
A
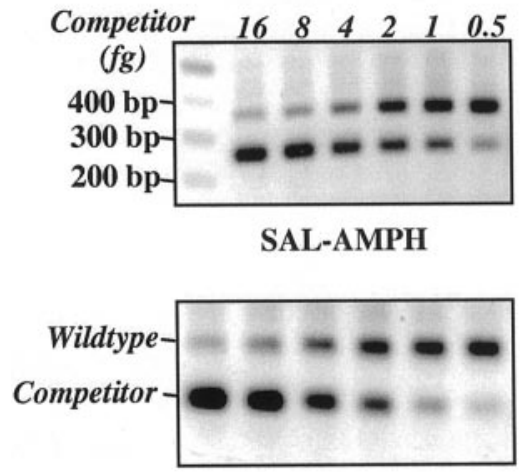

Figure 6. Effects of amphetamine on rat GIR expression in prefrontal cortex quantitatively determined by competitive PCR analysis and on locomotion activities measured by cumulative numbers of crossovers. $A$, Representative competitive PCR image. $B$, GIR mRNA levels calculated from linear regression plot of the ratio plotted logarithmically against initial amount of input competitor DNA. Values are expressed as mean \pm SEM $(n=6)$. SEs are represented by bars. denotes SAL-AMPH rats. denotes AMPH-AMPH rats. $C$, Cumulative numbers of crossovers measured during the 12-60 $\mathrm{min}$ and the 60-150 min periods after challenge injection. Values are expressed as mean $\pm \operatorname{SEM}(n=6)$. SEs are represented by bars. denotes AMPH-AMPH rats. D, Bar graph represents the increased levels of GIR mRNA in prefrontal cortex after withdrawal from chronic amphetamine exposure in a separate experiment without amphetamine challenge. Values are expressed as mean \pm $\operatorname{SEM}(n=6)$. SEs are represented by bars. $\square$ denotes SAL rats. denotes AMPH rats.
AMPH-AMPH
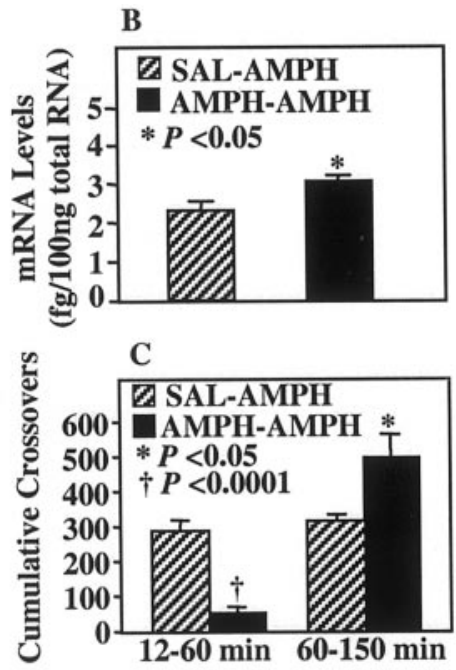

D

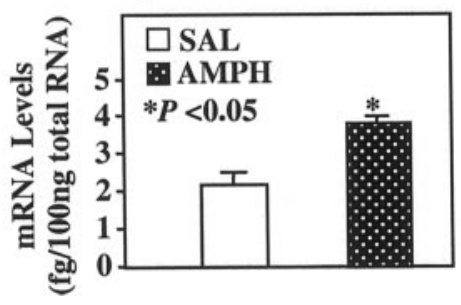

hanced CREB phosphorylation, alterations in the expression of transcription factors, particularly $\Delta \mathrm{FosB}$, and the activation of the hypothalamic-pituitary-adrenal axis (Hope et al., 1994; Turgeon et al., 1997; Koob, 1999; Nestler, 2000). Preliminary observations in rat amygdalar neuronal cells have shown an upregulation of GIR mRNA induced by dexamethasone or forskolin ( D. Wang and F. Sallee, unpublished results), in agreement with similar observations in mouse T lymphocytes (Harrigan et al., 1989). These findings support the hypothesis that glucocorticoid and cAMP are involved in the regulation of GIR gene expression. Further promoter analysis of the GIR gene expression may explain how the GIR gene could be regulated by cAMP, $\triangle$ FosBcontaining AP-1 complex, or steroid hormones.

In separate experiments, the amphetamine withdrawal group (AMPH) (Fig. 6D) and amphetamine challenge group (AMPH-AMPH) (Fig. 6B) had qualitatively similar increases in GIR mRNA expression that were not quantitatively equivalent ( $3.65 \pm 0.22$ vs $2.97 \pm 0.26 \mathrm{fg} / 100 \mathrm{ng}$ total RNA, respectively). Interanimal variability in male Sprague Dawley rats in response to repetitive AMPH has been previously described (Segal et al., 1987) and may account for the observed differences. Alternatively, the observation that the amphetamine withdrawal group (AMPH) and amphetamine challenge group (AMPH-AMPH) were not equivalent in GIR mRNA upregulation might reflect differential regulation of transcription factors in response to acute versus chronic psychostimulant administration. This phenomenon has been previously reported, whereby chronic cocaine exposure resulted in desensitization of immediate early genes induced by a subsequent cocaine challenge (Hope et al., 1992, 1998; Graybiel et al., 1995; Nye et al., 1995). This observation suggests that there might be specific transcription factors controlling GIR gene expression in response to acute versus chronic amphetamine administration. Further investigation needs to be performed to better elicit the molecular mechanisms surrounding the potential roles of GIR in adaptation to psychostimulants.

\section{REFERENCES}

Antelman SM, Eichler AJ, Black CA, Kocan D (1980) Interchangeability of stress and amphetamine in sensitization. Science 207:329-331.

Bouvier M, Collins S, O'Dowd BF, Campbell PT, de Blasi A, Kobilka BK, MacGregor C, Irons GP, Caron MG, Lefkowitz RJ (1989) Two distinct pathways for cAMP-mediated down-regulation of the beta 2-adrenergic receptor. Phosphorylation of the receptor and regulation of its mRNA level. J Biol Chem 264:16786-16792.

Cha X Y, Pierce RC, Kalivas PW, Mackler SA (1997) NAC-1, a rat brain mRNA, is increased in the nucleus accumbens three weeks after chronic cocaine self-administration. J Neurosci 17:6864-6871.

Casada JH, Dafny N (1991) Restraint and stimulation of the bed nucleus of the stria terminalis produce similar stress-like behaviors. Brain Res Bull 27:207-212.

Clark RB, Friedman J, Dixon RA, Strader CD (1989) Identification of a specific site required for rapid heterologous desensitization of the beta-adrenergic receptor by cAMP-dependent protein kinase. Mol Pharmacol 36:343-348.

De Moerlooze L, Williamson J, Liners F, Perret J, Parmentier M (2000) Cloning and chromosomal mapping of the mouse and human genes encoding the orphan glucocorticoid-induced receptor. Cytogenet Cell Genet 90:146-150.

Dohlman HG, Caron MG, DeBlasi A, Frielle T, Lefkowitz RJ (1990) Role of extracellular disulfide-bonded cysteines in the ligand binding function of the beta 2-adrenergic receptor. Biochemistry 29:2335-2342.

Gray TS, Piechowski RA, Yracheta JM, Rittenhouse PA, Bethea CL, Van de Kar LD (1993) Ibotenic acid lesions in the bed nucleus of the stria terminalis attenuate conditioned stress-induced increases in prolactin, ACTH and corticosterone. Neuroendocrinology 57:517-524.

Graybiel AM, Berretta S, Moratalla R, Liu FC, Elibol B (1995) Effects of cocaine on immediate-early gene response in striatal neurons In: The neurobiology of cocaine: cellular and molecular mechanisms (Hammer Jr RP, ed), pp 215-223. Boca Raton, FL: CRC.

Hamamura T, Fibiger HC (1993) Enhanced stress-induced dopamine release in the prefrontal cortex of amphetamine-sensitized rats. Eur J Pharmacol 237:65-71.

Harrigan MT, Baughman G, Campbell NF, Bourgeois S (1989) Isolation and characterization of glucocorticoid- and cyclic AMP-induced genes in T lymphocytes. Mol Cell Biol 9:3438-3446.

Harrigan MT, Campbell NF, Bourgeois S (1991) Identification of a gene 
induced by glucocorticoids in murine T-cells: a potential G proteincoupled receptor. Mol Endocrinol 5:1331-1338.

Henke PG (1984) The bed nucleus of the stria terminalis and immobilization stress: Unit activity, escape behavior and gastric pathology in rats. Behav Brain Res 11:35-45.

Hope BT (1998) Cocaine and the AP-1 transcription factor complex. Ann NY Acad Sci 844:1-6.

Hope BT, Kosofsky B, Hyman SE, Nestler EJ (1992) Regulation of immediate early gene expression and AP-1 binding in the rat nucleus accumbens by chronic cocaine. Proc Natl Acad Sci USA 89:5764-5768.

Hope BT, Nye HE, Kelz MB, Self DW, Iadarola MJ, Nakabeppu Y, Duman RS, Nestler EJ (1994) Induction of a long-lasting AP-1 complex composed of altered Fos-like proteins in brain by chronic cocaine and other chronic treatments. Neuron 13:1235-1244.

Jakab RL, Leranth C (1995) Septum. In: The rat nervous system, Ed 2 (Paxinos G, ed), pp 405-442. San Diego: Academic.

Kalivas PW, Duffy P (1989) Similar effects of daily cocaine and stress on mesolimbic dopamine neurotransmission in the rat. Biol Psychiatry 25:913-928.

Kalivas PW, Nakamura M (1999) Neural systems for behavioral activation and reward. Curr Opin Neurobiol 9:223-227.

Kalivas PW, Stewart J (1991) Dopamine transmission in the initiation and expression of drug- and stress-induced sensitization of motor activity. Brain Res Rev 16:223-244.

Karler R, Finnegan KT, Calder LD (1993) Blockade of behavioral sensitization to cocaine and amphetamine by inhibitors of protein synthesis. Brain Res 603:19-24.

Kelz MB, Nestler EJ (2000) deltaFosB: a molecular switch underlying long-term neural plasticity. Curr Opin Neurol 13:715-720.

Kelz MB, Chen J, Carlezon Jr WA, Whisler K, Gilden L, Beckmann AM, Steffen C, Zhang YJ, Marotti L, Self DW, Tkatch T, Baranauskas G, Surmeier DJ, Neve RL, Duman RS, Picciotto MR, Nestler EJ (1999) Expression of the transcription factor deltaFosB in the brain controls sensitivity to cocaine. Nature 401:272-276.

Kozak M (1991) Structural features in eukaryotic mRNAs that modulate the initiation of translation. J Biol Chem 266:19867-19870.

Koob GF (1999) Stress, corticotropin-releasing factor, and drug addiction. Ann NY Acad Sci 897:27-45.

Kramer MS, Cutler N, Feighner J, Shrivastava R, Carman J, Sramek JJ, Reines SA, Liu G, Snavely D, Wyatt-Knowles E, Hale JJ, Mills SG, MacCoss M, Swain CJ, Harrison T, Hill RG, Hefti F, Scolnick EM, Cascieri MA, Chicchi GG, Sadowski S, Williams AR, Hewson L, Smith D, Rupniak NM (1998) Distinct mechanism for antidepressant activity by blockade of central substance $\mathrm{P}$ receptors. Science 281:1640-1645.

Murtra P, Sheasby AM, Hunt SP, De Felipe C (2000) Rewarding effects of opiates are absent in mice lacking the receptor for substance $\mathrm{P}$. Nature 405:180-183.

Nestler EJ (2000) Genes and addiction. Nat Genet 26:277-281.

Nye HE, Hope BT, Kelz MB, Iadarola M, Nestler EJ (1995) Pharmacological studies of the regulation of chronic FOS-related antigen induction by cocaine in the striatum and nucleus accumbens. J Pharmacol Exp Ther 275:1671-1680.

O’Dowd BF, Hnatowich M, Caron MG, Lefkowitz RJ, Bouvier M (1989) Palmitoylation of the human beta 2-adrenergic receptor. Mutation of Cys341 in the carboxyl tail leads to an uncoupled nonpalmitoylated form of the receptor. J Biol Chem 264:7564-7569.

Parker R, Liu M, Eyre HJ, Copeland NG, Gilbert DJ, Crawford J, Sutherland GR, Jenkins NA, Herzog H (2000) Y-receptor-like genes GPR72 and GPR73: molecular cloning, genomic organisation and assignment to human chromosome $11 \mathrm{q} 21.1$ and 2 p14 and mouse chromosome 9 and 6. Biochim Biophys Acta 1491:369-375.

Pesini P, Detheux M, Parmentier M, Hokfelt T (1998) Distribution of a glucocorticoid-induced orphan receptor (JP05) mRNA in the central nervous system of the mouse. Brain Res Mol Brain Res 57:281-300.

Pierce RC, Kalivas PW (1997) A circuitry model of the expression of behavioral sensitization to amphetamine-like psychostimulants. Brain Res Rev 25:192-216.

Price JL (1995) Thalamus. In: The rat nervous system, Ed 2 (Paxinos G, ed), pp 629-648. San Diego: Academic.

Raeymaekers L (1999) General principle of quantitative PCR. In: Quantitative PCR protocol (Kochanowski B, Reischl U, eds), pp 31-41. Totowa, NJ: Humana.

Robinson TE, Becker JB (1986) Enduring changes in brain and behavior produced by chronic amphetamine administration: a review and evaluation of animal models of amphetamine psychosis. Brain Res 396:157-198.

Richtand NM, Logue AD, Welge JA, Perdiue J, Tubbs LJ, Spitzer RH, Sethuraman G, Geracioti TD (2000) The dopamine D3 receptor antagonist nafadotride inhibits development of locomotor sensitization to amphetamine. Brain Res 867:239-242.

Segal DS, Kuczenski R (1974) Tyrosine hydroxylase activity: regional and subcellular distribution in the brain. Brain Res 68:261-266.

Segal DS, Kuczenski R (1987) Individual differences in responsiveness to single and repeated amphetamine administration: behavioral characteristics and neurochemical correlates. J Pharmacol Exp Ther 242:917-926.

Segal DS, Kuczenski R (1994) Behavioral pharmacology of amphetamine. In: Amphetamine and its analogs: neuropharmacology, toxicology, and abuse (Cho A, Segal DS, eds), pp 115-150. Orlando, FL: Academic.

Segal DS, Weinberger SB, Cahill J, McCunney SJ (1980) Multiple daily amphetamine administration: behavioral and neurochemical alterations. Science 207:905-907.

Shipley MT, McLean JH, Ennis M (1995) Olfactory system. In: The rat nervous system, Ed 2 (Paxinos G, ed), pp 899-928. San Diego: Academic.

Siebert PD, Larrick JW (1992) Competitive PCR. Nature 359:557-558.

Sorg BA, Ulibarri C (1995) Application of a protein synthesis inhibitor into the ventral tegmental area, but not the nucleus accumbens, prevents behavioral sensitization to cocaine. Synapse 20:217-224.

Strader CD, Sigal IS, Register RB, Candelore MR, Rands E, Dixon RA (1987) Identification of residues required for ligand binding to the beta-adrenergic receptor. Proc Natl Acad Sci USA 84:4384-4388.

Strader CD, Fong TM, Tota MR, Underwood D, Dixon RA (1994) Structure and function of $\mathrm{G}$ protein-coupled receptors. Annu Rev Biochem 63:101-132.

Swanson LW (1987) The hypothalamus. In: Handbook of chemical neuroanatomy (Björklund A, Hökfelt T, Swanson LW, eds), pp 1-124. Amsterdam: Elsevier.

Turgeon SM, Pollack AE, Fink JS (1997) Enhanced CREB phosphorylation and changes in c-Fos and FRA expression in striatum accompany amphetamine sensitization. Brain Res 749:120-126.

Vanderschuren LJ, Kalivas PW (2000) Alterations in dopaminergic and glutamatergic transmission in the induction and expression of behavioral sensitization: a critical review of preclinical studies. Psychopharmacology 151:99-120.

von Heijne G (1986) A new method for predicting signal sequence cleavage sites. Nucleic Acids Res 14:4683-4690.

White FJ, Kalivas PW (1998) Neuroadaptations involved in amphetamine and cocaine addiction. Drug Alcohol Depend 51:141-153.

Wolf ME (1998) The role of excitatory amino acids in behavioral sensitization to psychomotor stimulants. Prog Neurobiol 54:679-720.

Wolf ME, Dahlin SL, Hu XT, Xue CJ, White K (1995) Effects of lesions of prefrontal cortex, amygdala, or fornix on behavioral sensitization to amphetamine: comparison with $N$-methyl-D-aspartate antagonists. Neuroscience 69:417-439. 